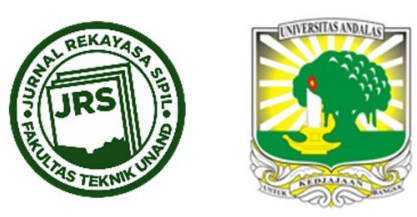

\title{
PENGARUH WAKTU TERHADAP DAYA DUKUNG FONDASI TIANG PADA TANAH LUNAK DENGAN VARIASI KEKASARAN
}

\author{
ZONI SATRIA $^{1}$, FERRY FATNANTA ${ }^{{ }^{*}}$, SOEWIGNJO AGUS NUGROHO ${ }^{1}$ \\ ${ }^{1}$ Teknik Sipil, Jurusan Teknik Sipil, Fakultas Teknik, Universitas Riau \\ *Corresponding author: $₫$ fatnanto1964@gmail.com
}

Naskah diterima : 15 Januari 2020. Disetujui: 26 Maret 2020

\begin{abstract}
ABSTRAK
Kapasitas daya dukung tanah lunak sangat kecil, untuk peningkatan daya dukung digunakan fondasi tiang friksi yang menggunakan kekasaran permukaan tiang dengan waktu pemancangan yang telah ditentukan yaitu $0,4,8,16,32$, dan 64 hari. Tujuan penelitian ini adalah Menentukan seberapa besar peningkatan kapasitas daya dukung fondasi tiang dengan variasi kekasaran permukaan tiang dan waktu pengujian pembebanan. Pengujian pembebanan menggunkan metode CRP (Constant Rate of Penetration Method) sedangkan untuk interpretasi kapasitas aksial tiang pancang menggunakan metode Terzaghi dan Peck. Semua variasi waktu akan dianalisis dan dibandingkan hasil daya dukung aksial dari fondasi tiang polos, kekasaran spasi dan kekasaran penuh. Hasil penelitian menunjukan peningkatan daya dukung selalu meningakat dari umur 0 sampai 64 hari. Kapasitas daya dukung fondasi tiang terbesar terdapat pada tiang kekasaran spasi yaitu 55,9 N. tiang kekasaran penuh sebesar $54,5 \mathrm{~N}$ dan tiang polos sebesar 22,8 $\mathrm{N}$. Faktor peningkatan daya dukung $(\Delta 10)$ tiang polos sebesar 0,04, tiang spasi 0,07 dan tiang penuh 0,09 dengan waktu referensi (to) $=1$ hari. Faktor peningkatan $(\Delta 10)$ menunjukan faktor peningkatan kapasitas daya dukung tiang seiringnya dengan pertambahan waktu.
\end{abstract}

Kata kunci : tanah lunak, kekasaran, waktu pemancangan, fondasi tiang friksi

\section{PENDAHULUAN}

Tanah lunak dalam konstruksi sering kali menjadi permasalahan. Hal ini disebabkan oleh rendahnya daya dukung tanah tersebut. Dalam menanggulangi permasalahan tersebut, maka diperlukan pekerjaan perbaikan tanah. Tanah lunak merupakan tanah kohesif yang terdiri dari sebagian besar butir-butir yang kemampatannya besar, koefisien permeabilitas yang kecil dan mempunyai daya dukung rendah jika dibandingkan dengan tanah lempung lainnya.

Fondasi dibuat menjadi satu kesatuan dasar bangunan yang kuat dan terdapat dibawah kosntruksi. Untuk merencanakan suatu fondasi yang akurat, secara umum ada dua hal yang 
harus perlu diperhatikan yaitu daya dukung tanah fondasi dan penurunan fondasi. Untuk dapat dihitung kedua hal di atas, diperlukan data parameter tanah dimana fondasi akan didirikan. Permasalahan yang sering terjadi pada daya dukung tanah lunak sangat kecil, maka untuk peningkatan daya dukung digunakan fondasi tiang friksi yang diberikan menggunakan kekasaran permukaan tiang dengan waktu pengujian pembebanan yang telah ditentukan yaitu $0,4,8,16,32$, dan 64 hari. Variasi waktu setelah pemancangan sebagai bentuk untuk pemulihan perilaku tanah yang terganggu saat proses pemancangan

Penelitian ini dilakukan dengan membuat model tiang friksi (friction pile)terbuat dari beton yang berisi tulangan dengan skala laboratorium yang akan dipasang pada sebuah bak yang berisi tanah lunak, dengan kekasaran permukaan tiang, model tiang tersebut kemudian diuji daya dukungnya dengan pengujian pembebanan. Pada penelitian yang telah dilakukan sebelumnya menunjukkan bahwa pemberian perkuatan pada dinding fondasi dapat meningkatkan nilai daya dukung fondasi. Fakta di lapangan ditemukan fenomena bahwa kapasitas aksial tiang pancang mengalami peningkatan seiring waktu, yang diyakini sebagai waktu untuk pemulihan tanah dari gangguan setelah pemancangan. Dari beberapa penelitian, telah tercatat adanya peningkatan kapasitas tiang seiring dengan pertambahan waktu (A. Augustesen, Andersen, \& Sørensen, 2005). Oleh sebab itu dilakukan penelitian untuk meningkatkan kapasitas daya dukung fondasi tiang terhadap variasi kekasaran. Penggunaan fondasi tiang untuk perbaikan tanah lunak sudah sejak lama digunakan, baik dari bahan kayu, beton, ataupun baja. Dalam Soil/Pile Set-up Effects on Driven Pile in Malaysian Soil oleh Ng, D’Applonia (1971) mengatakan bahwa pemancangan tiang pada tanah lempung berbeda dengan tanah pasir. Pada tanah kohesif, tanah di bawah tiang terdorong secara lateral keluar dari jari-jari tiang dan memicu kegagalan geser tanah di saat pemancangan. Khususnya pada tiang friksi (friction pile) yang pemancangannya tidak mencapai tanah keras, jika dipukul/ditekan terus menerus maka tiang akan terus tertanam lebih dalam tanpa suatu batas tanah keras. Pada tiang ini, besarnya kapasitas aksial tiang bergantung pada gaya kontak/friksi antara selimut tiang dengan tanah di sekitarnya.

\section{DAYA DUKUNG FONDASI TIANG}

\subsection{Tes Pembebanan Fondasi Tiang (Pile Loading Test)}

Tes pembebanan tiang merupakan suatu metode yang dilakukan dalam memeriksa kemampuan struktur untuk mendukung sejumlah beban, struktur tersebut adalah fondasi. Tes ini diperlukan untuk memberikan ketepatan perhitungan dalam desain kapasitas daya dukung fondasi tiang di lapangan.

\subsection{Penurunan (Sett/ement)}

Perencanaan suatu fondasi bangunan harus memperhatikan dua hal, antara lain (Wesley, 1977):

a) Daya dukung tanah yaitu apakah tanah itu cukup kuat untuk menahan beban fondasi tanpa terjadi keruntuhan akibat menggeser. Tentu saja hal ini tergantung pada kekuatan geser tana.

b) Penurunan yang terjadi, hal ini tergantung pada macam tanah.

\subsection{Fondasi Tiang}

Fondasi tiang adalah bagian konstruksi yang dibuat dari kayu, beton dan/atau baja, yang 
digunakan untuk meneruskan (mentransmisikan) beban permukaan ke tingkat permukaan yang lebih rendah dalam massa tanah. Beban terdistribusi sebagai beban vertikal dari beban sepanjang poros tiang pancang atau pemakaian beban secara langsung terhadap lapisan yang lebih rendah melalui ujung tiang pancang, Bowles (1991). Jenis fondasi ini digunakan bilamana letak tanah keras sangat dalam, yang yang umumnya dinyatakan dalam rasio Df/B $>10$. Di atas lapisan tanah keras dijumpai lapisan tanah lunak dengan kuat dukung rendah. Jadi tanah keras ini mendukung beban yang yang bekerja, dan struktur tiang harus mampu menerima beban yang mengakibatkan terjadinya lentur atau tarik. Bentuk tampang tiang dapat berbentuk lingkaran, segi empat, segi enam, segi delapan, bahkan tidak beraturan.

\subsection{Pengaruh Waktu Pada Fondasi}

Penentuan kapasitas tiang untuk jangka panjang sangat diperlukan dalam perencanaan dan konstruksi fondasi tiang pada tanah kohesif. Suatu persamaan linier dalam skala waktu logaritmik telah diperoleh untuk memprediksikan besarnya peningkatan kapasitas aksial tiang dengan waktu setelah pemancangan mampu memberikan berbagai keuntungan (Svinkin \& Mark, 1997). Beberapa penelitian, telah tercatat adanya peningkatan kapasitas tiang seiring dengan pertambahan waktu. Waktu yang mempengaruhi mengacu pada waktu yang berlalu sejak akhir dari proses pemancangan. Dan waktu ini tidak diasosiasikan dengan pembebanan siklus ataupun tingkat pembebanan.

Beberapa penelitian, telah tercatat adanya peningkatan kapasitas tiang seiring dengan pertambahan waktu. Waktu yang mempengaruhi mengacu pada waktu yang berlalu sejak akhir dari proses pemancangan. Dan waktu ini tidak diasosiasikan dengan pembebanan siklus ataupun tingkat pembebanan. Peningkatan kapasitas tiang ini diyakini disebabkan oleh dua fakor yang bebeda (A. Augustesen et al., 2005). Sedangkan menurut Komurka, Wagner, and Edil (2003), peningkatan kapasitas aksial tiang yang disebabkan oleh tanah itu sendiri, tergantung pada sifat kohesi, campuran tanah, dan ukuran butiran tanahnya.

Perbedaan kekasaran permukaan tiang juga mempengaruhi tingkat interaksi antar partikel butiran tanah dan tiang (Ravishankar, 2006). Ini berarti lebih besar peningkatan kapasitas tiang beton dari pada tiang baja. Dalam The Effects of Time on Soil Behaviour and Pile Capacity (A. H. Augustesen, 2006) disebutkan sebuah hubungan linier semi-logaritmik oleh Skov and Denver (1988) yang digunakan untuk menjabarkan hubungan antara waktu, t, dan kapasitas dukung tiang, Q. Data yang telah ada, Lied (2010) menyatakan bahwa kapasitas aksial tiang pada tanah lempung mampu meningkat sebanyak 10-50\% dalam 1 hingga 2 tahun setelah pemancangan dan 50-100\% setelah 10 tahun. Ada juga beberapa keterangan bahwa kapasitas tiang juga bisa meningkat secara signifikan seiring dengan waktu pada fondasi di tanah pasir.

\subsection{Metode Pengujian Fondasi}

Metode CRP merupakan salah satu alternatif lain untuk pengujian tiang secara statis. Prosedurnya adalah dengan membebani tiang secara terus - menerus hingga kecepatan penetrasi ke dalam tanah konstan. Umumnya diambil patokan sebesar $0.245 \mathrm{~cm} / \mathrm{menit}$ atau lebih rendah bila jenis tanah adalah lempung. Hasil pengujian tiang dengan metode CRP menunujukkan bahwa beban runtuh relative tidak tergantung oleh kecepatan penetrasi bila digunakan batasan kecepatan penurunan kurang dari $0.125 \mathrm{~cm} /$ menit. Kecepatan yang lebih tinggi dapat menghasilkan daya dukung yang sedikit. Beban dan pembacaan deformasi diambil setiap menit. Pengujian dihentikan bila pergerakan total kepala tiang mencapai $10 \%$ dari diameter tiang bila pergerakan (displacement) sudah cukup besar. 


\subsection{Interpretasi Kapasitas Aksial Pancang}

Menurut Terzaghi and Peck (1967), fondasi persegi dan menerus dengan lebar yang sama menunjukkan perilaku penurunan yang sama untuk intensitas beban dan tanah yang sama. Bahwa metode ini merupakan metode penentuan daya dukung ultimit berdasarkan beban yang sesuai dengan penurunan $25 \mathrm{~mm}\left(\mathrm{Q}_{25}\right)$. Berbagai penelitian yang telah dilakukan sebelumnya menyatakan bahwa metode Terzaghi dan Peck lebih konservatif dibandingkan beberapa metode lainnya Metode interpretasi daya dukung yang digunakan dalam penelitian ini adalah metode Terzaghi dan Peck. Perhitungan dilakukan untuk melakukan interpretasi pada data dari hasil yang dikeluarkan oleh pengujian aksial tekan (axial compression). Dengan metode perhitungan, maka akan menghasilkan besar nilai kekuatan dari fondasi tiang agar dapat menyalurkan beban dengan baik dan menghindari dari keruntuhan. Beban dari keruntuhan tersebut dapat dikatakan sebagai beban dimana saat fondasi tiang mengalami penurunan dengan cepat saat melakukan pembebanan selanjutnya. Dengan kata lain, penurunan tersebut telah membuat terjadinya pergerakan yang besar yang telah melewati batas maksimum yang dimiliki oleh fondasi tiang. interpretasi daya dukung ultimit dengan metode terzaghi dan peck dapat dilihat Gambar 1.

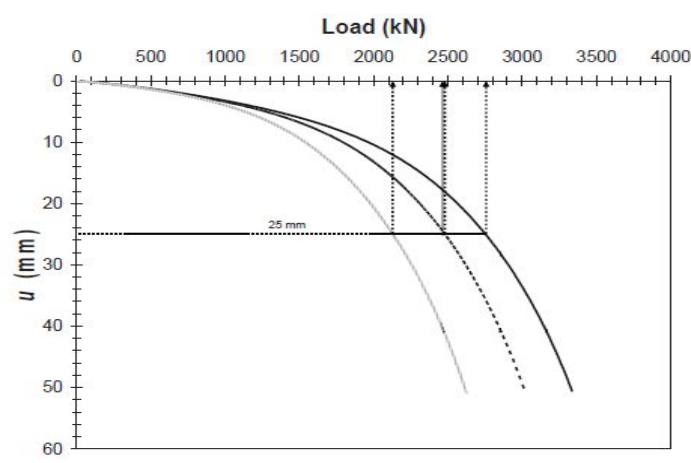

Gambar 1. Interpretasi Daya Dukung Ultimit dengan Terzaghi dan Peck

\section{METODOLOGI PENELITIAN}

\subsection{Prosedur Penelitian}

Beberapa tahapan yang perlu dilakukan untuk melaksanakan suatu penelitian, yaitu studi literatur, survey lokasi dan pengambilan tanah di lapangan, pengujian di laboratorium, dan analisis data. 

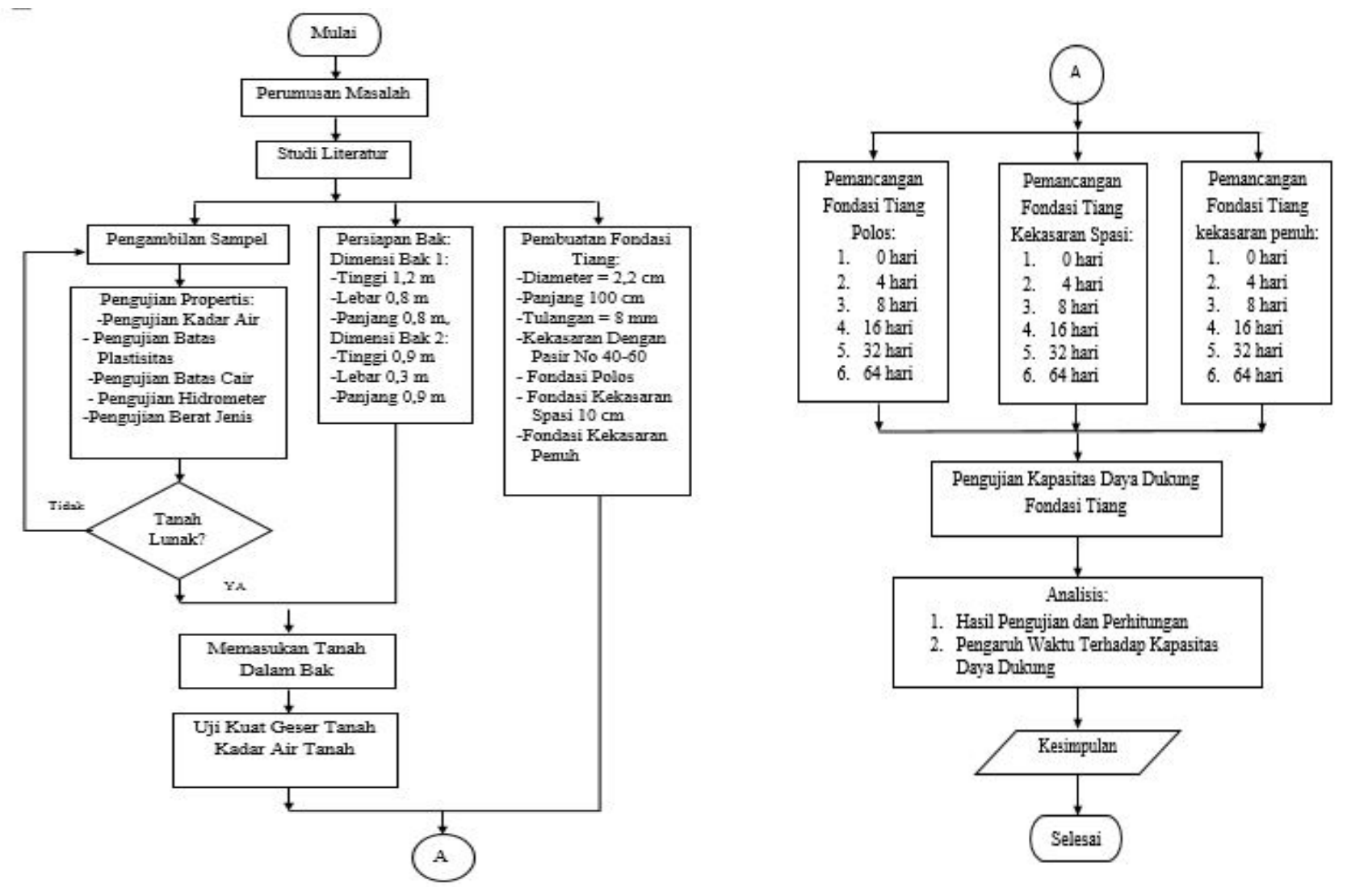

Gambar 2. Bagan Alir Penelitian

\subsection{Lokasi Penelitian}

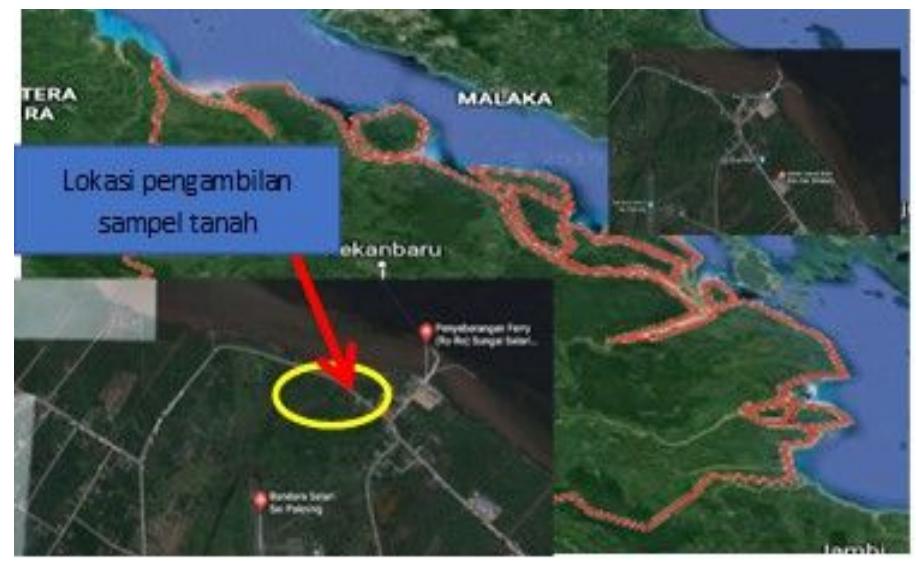

Gambar 3. Lokasi Penelitian

Tanah lunak yang digunakan diambil dari daerah Sungai Pakning, Kabupaten Bengkalis, Provinsi Riau, tepatnya tidak jauh dari pelabuhan roro.

\subsection{Bahan dan Alat Pengujian}

Bahan yang dugunakan dalam penelitian ini dalah tanah lunak yang diambil dari daerah Sungai Pakning, Kabupaten Bengkalis, Provinsi Riau, tepatnya tidak jauh dari pelabuhan 
roro. Pengujian yang dilakukan terdiri dari pengujian karakteristik tanah yang meliputi pengujian kadar air, vane shear, berat jenis tanah, hidrometer, batas cair dan batas plastis, serta pengujian permodelan fondasi yang sesuai dengan waktu yang telah ditentukan. Model fondasi tiang penampang lingkaran dengan diameter $2,2 \mathrm{~cm}$ dan panjang $100 \mathrm{~cm}$ yang terbuat dari adukan semen dan pasir yang berisi tulangan dengan diameter $8 \mathrm{~mm}$. untuk bak yang digunakan ada dua bak, Bak A berukuran tinggi $1,2 \mathrm{~m}$ x lebar $0,8 \mathrm{~m} \times$ panjang $0,8 \mathrm{~m}$ yang kedap air dan diberikan portal tempat bertumpunya alat uji tekan dan Bak B berukuran tinggi $0,9 \mathrm{~m} \times$ lebar $0,3 \mathrm{~m} \times$ panjang $0.9 \mathrm{~m}$ yang kedap airdan diberikan portal tempat bertumpunya alat uji tekan.

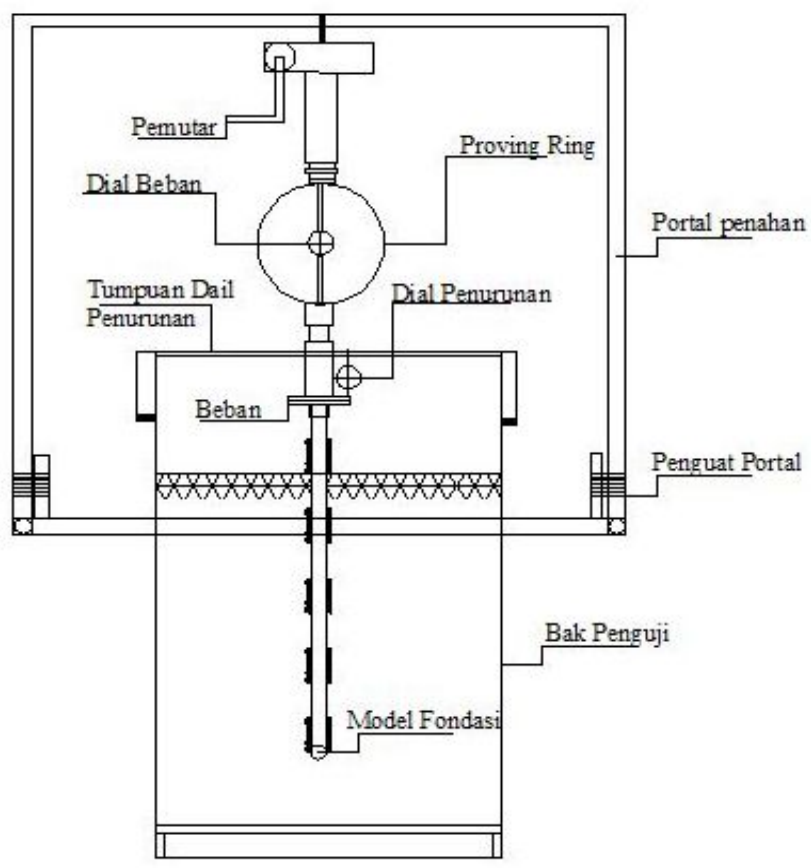

Gambar 4. Alat Pengujian Penelitian

\subsection{Penamaan Fondasi Tiang}

Penelitan menggunakan tiga tipe pemodelan fondasi tiang yaitu fondasi tiang dengan kekasaran penuh, fondasi tiang kekasaran spasi, dan fondasi tiang polos. Untuk penamaan tiang dapat dilihat pada Tabel 1.

Tabel 1. Penamaan Fondasi Tiang

\begin{tabular}{llll}
\hline Waktu & Tiang & \multicolumn{2}{l}{ Tiang Dengan Kekasaran } \\
\cline { 3 - 4 } & Polos & Tiang Spasi & Tiang Penuh \\
\hline Hari & TA & TB & TC \\
\hline 0 & TA0 & TB0 & TC0 \\
\hline 4 & TA4 & TB4 & TC4 \\
\hline 8 & TA8 & TB8 & TC8 \\
\hline 16 & TA16 & TB16 & TC16 \\
\hline 32 & TA32 & TB32 & TC32 \\
\hline 64 & TA64 & TB64 & TC64 \\
\hline
\end{tabular}



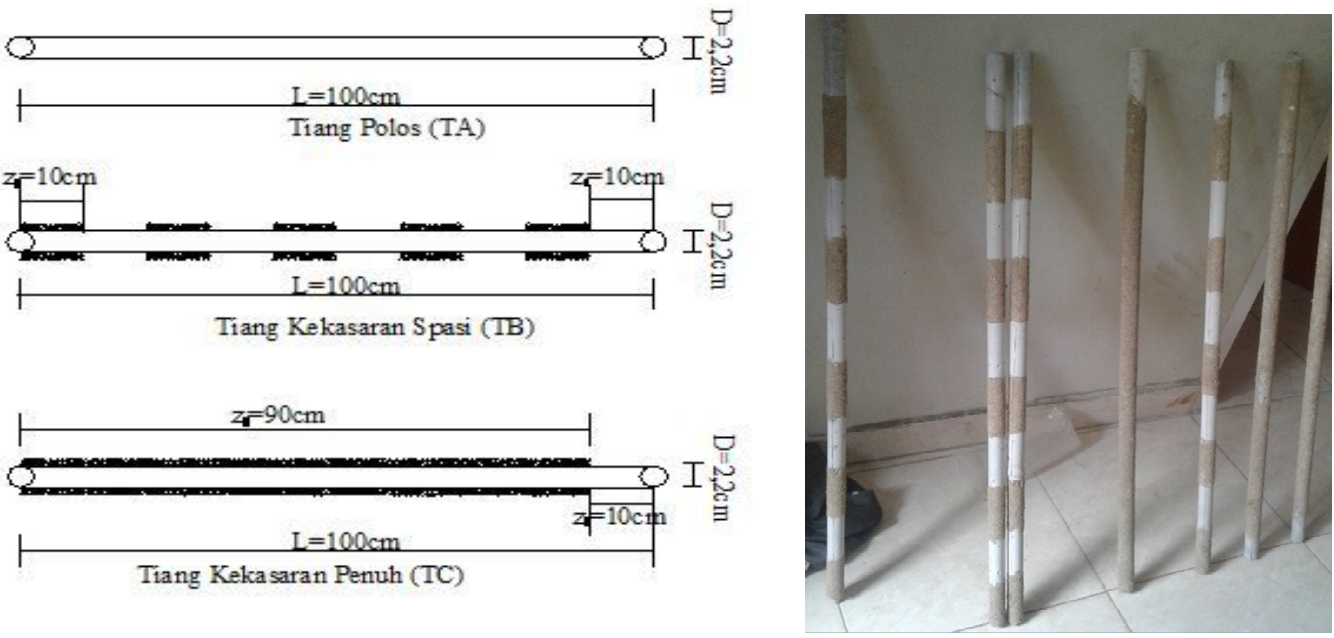

Gambar 5. Model Fondasi Tiang Kekasaran dan Polos

Tabel 1 dan Gambar 5. menjelaskan penamaan tiang pancang, tiang pancang dalam penelitian ini terdiri dari 3 jenis yaitu tiang pancang polos (TA), tiang pancang menggunakan kekasaran berspasi (TB), dan tiang pancang menggunakan kekasaran penuh (TC). Kekasaran yang digunakan pada tiang spasi yaitu dengan jarak $10 \mathrm{~cm}$ kemudian $10 \mathrm{~cm}$ selanjutnya polos dan $10 \mathrm{~cm}$ selanjutnya kekasaran dan begitu seterusnya sampai $100 \mathrm{~cm}$. sedangkan untuk kekasaran fondasi tiang penuh dengan ukuran $90 \mathrm{~cm}$ untuk kekasaran dan $10 \mathrm{~cm}$ polos. Selanjutnya untuk fondasi tiang polos tidak diberi kekasaran. Cara memberikan kekasaran pada permukaan tiang dengan menggunakan lem perekat, lem tersebut dioles pada permukaan tiang kemudian menempelkan pasir yang sudah disaring.

\subsection{Persiapan Sampel Tanah}

Proses memasukan tanah lunak ke dalam bak pengujian dilakukan sedikit demi sedikit dan hati-hati, supaya tidak terdapat rongga udara yang terdapat antara gumpalan tanah. Setelah pengisian tanah selesai dilakukan, penjagaan terhadap kadar air dan kuat geser tanah terus dilakukan, dengan cara menutup tanah dengan kain basah/lembah, sehingga tidak terjadi penguapan air tanah. Kontrol kualitas selalu dilakukan setiap kali pengujian pembebanan dilakukan. Dan kuat geser tanah tidak dikoreksi terhadap plastisitasnya.

Pengujian kuat geser tanah dilakukan setiap saat dilakukannya pengujian pembebanan terhadap model fondasi dengan menggunakan alat vane shear, kemudian diikuti dengan pengambilan sampel tanah hasil pengujian kuat geser untuk pemeriksaan kadar air. Pada penelitian ini untuk nilai koreksi baling-baling Vane shear digunakan baling-baling dengan ukuran 16 x $32 \mathrm{~mm}$ dengan nilai koreksi ke kPa = 2 (Arianto, 2010).

Data dari hasil penelitian di laboratorium dikumpulkan dan disusun dalam bentuk tabel dan grafik dianalisis dengan metode Terzaghi dan Peck untuk mendapatkan nilai daya dukung penurunan $25 \mathrm{~mm}\left(\mathrm{Q}_{25}\right)$.

\section{HASIL DAN PEMBAHASAN}

\subsection{Hasil Sifat Fisik dan Propertis Tanah}

Sebelum melakukan pengujian pembebanan terlebih dahulu menguji sifat fisik tanah dan propertis tanah yang akan digunakan dalam penelitian ini. Terlebih dahulu diuji di 
laboratorium Mekanika Tanah Jurusan Teknik Sipil Universitas Riau. Hasil uji sifat-sifat fisik tanah yang digunakan dalam pengujian ini dapat dilihat pada Tabel 2 di bawah ini

Tabel 2. Hasil Uji Sifat-Sifat Fisik Tanah

\begin{tabular}{lll}
\hline Sifat dan Krakteristik Tanah & Satuan & Hasil \\
\hline Kadar Air Rata-Rata dalam Bak & $\%$ & 103,93 \\
\hline Spesifik Gravity & - & 2,4 \\
\hline Kuat Geser (Su) Rata- Rata dan Bak & $\mathrm{kPa}$ & 4,31 \\
\hline Batas Cair (LL) & $\%$ & 60,22 \\
\hline Batas Plastisitas (PL) & $\%$ & 36,82 \\
\hline Indeks Plastisitas (IP) & $\%$ & 23,40 \\
\hline Hidrometer: pasir & $\%$ & 6,15 \\
\hline Hidrometer: lempung & $\%$ & 93,85 \\
\hline
\end{tabular}

\subsection{Kuat Geser Tanah dan Kadar Air Tanah}

Hasil pengujian kuat geser tanah seiring dengan waktu pengujian pembebanan dapat dilihat pada Gambar 6 di bawah ini.

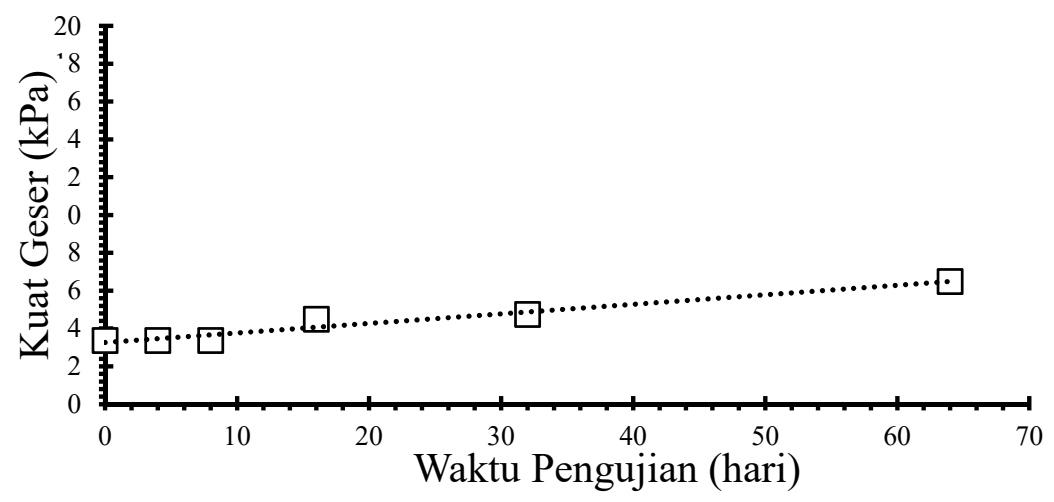

Gambar 6. Pengujian Kuat Geser Tanah Rata-Rata dengan Waktu Pengujian

Berdasarkan Gambar 6. hasil pengujian kuat geser tanah dengan waktu pengujian menunjukan bahwa tanah yang semakin lama pemeraman mengalami peningkatan kuat geser tanah seperti umur 0 hari kuat geser tanahnya $3,375 \mathrm{kPa}$ dan untuk umur 32 hari dengan kuat geser tanah yaitu 4,75 kPa sedangkan untuk umur 64 hari dengan kuat geser $6,5 \mathrm{kPa}$ sehingga didapat selisih untuk kuat geser sebesar $3.125 \mathrm{kPa}$. Hal ini disebabkan oleh penurunan kadar air selama waktu pemeraman.

Pengujian kadar air tanah dilakukan pada setiap pengujian tiang yang waktu pengujinya sudah ditentukan. Pengujian kadar air ini bertujuan untuk melihat perubahan dari kadar air selama proses pengujian tiang. Hasil dari pengaruh kadar air dikaitkan dengan perubahan kapasitas daya dukung fondasi selama umur pemancangan fondasi tiang. 


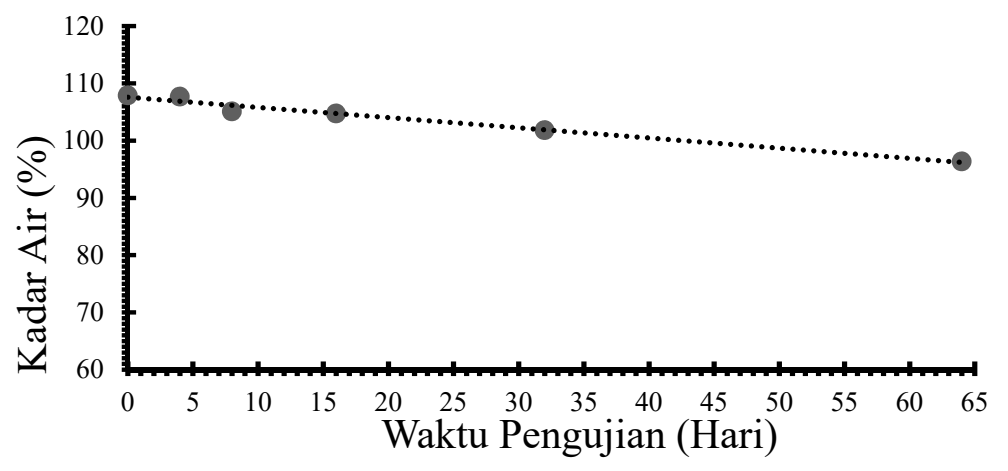

Gambar 7. Pengujian Kadar Air Rata-Rata dengan Waktu Pengujian

Gambar 7. Tentang pengujian kadar air rata-rata dengan waktu pengujian. Hal ini menunjukan bahwa kadar air tanah mengalami penurunan selama waktu pemeraman tiang fondasi. Dimana selisih kadar air dari umur 0 hari sampai umur 64 hari yaitu sebesar $11,52 \%$. Oleh sebab itu terjadi penguapan air di dalam bak tanah selama pemeraman berlangsung dan juga diakibatkan oleh sinar matahari langsung ke bak pengujian selama pemeraman berlangsung. Namun kadar air tersebut dalam Tabel 4.3 berada diatas batas cair, sebesar $60,22 \%$.

\subsection{Hasil Pengujian Fondasi Tiang Aksial}

Pengujian tiang fondasi kekasaran penuh, spasi dan polos dengan jumlah 3 tiang pada setiap hari pengujian $0,4,8,16,32$, dan 64 hari. Hasil pengujian tersebut digambarkan dengan menggunakan grafik yang menghubungkan antara beban dan penurunan yang diakibatkan oleh umur pemancangan tiang tersebut dan bias dilihat pada Gambar 6 .
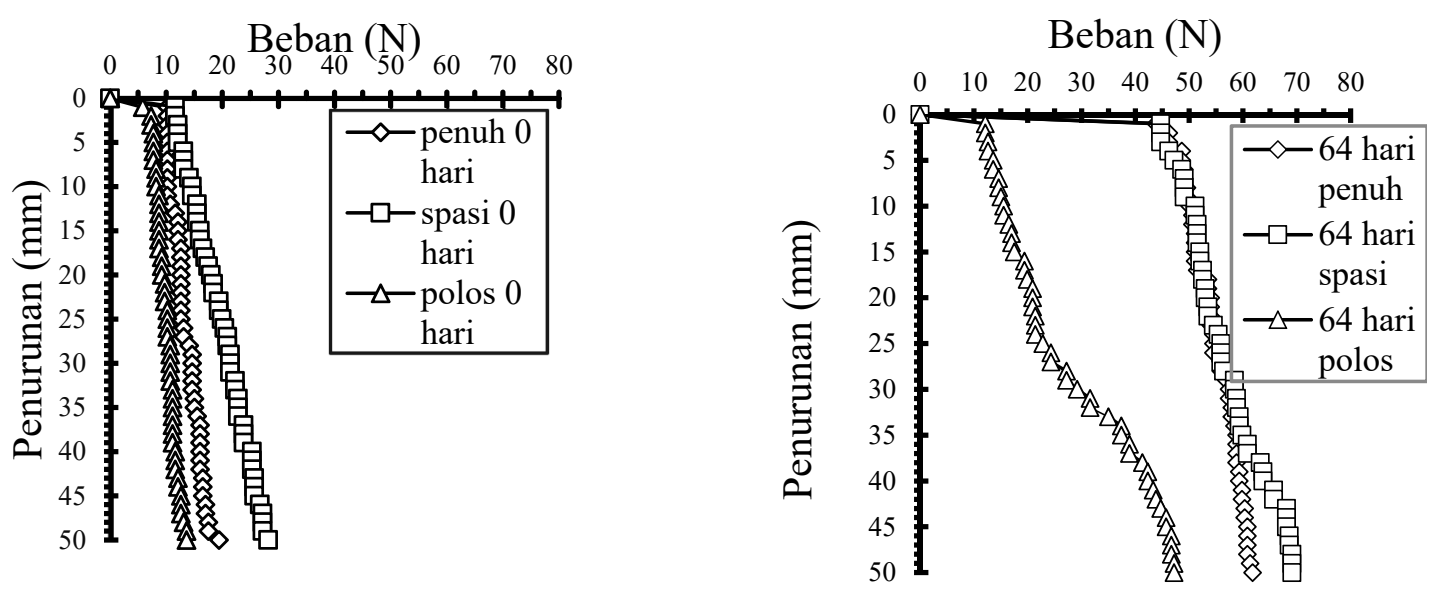

Gambar 8. Pengujian Penurunan (mm) dengan Beban (N)

Pengujian penurunan dengan beban tiang fondasi umur 0 hari dan 64 hari pada Gambar 8. menjelaskan tentang tiang fondasi mengalami peningkatan daya dukung seiringnya waktu pengujian. Untuk model tiang fondasi umur o hari memiliki nilai daya dukung yang berdekatan bahkan hampir berhimpitan, tetapi tiang fondasi kekasaran memilki daya dukung paling besar. Sedangkan model tiang fondasi umur 64 hari memiliki rentang nilai daya dukung berjauhan. Nilai daya dukung tiang polos tidak berpengaruh terhadap umur pemeramam. Sedangan untuk tiang kekasaran spasi dan penuh memiliki nilai daya dukung yang berhimpitan. Tetapi tiang fondasi kekasaran spasi memiliki nilai daya dukung paling 
besar. Hal ini disebabkan oleh penguapan air dalam bak selama pemeraman dan sinar matahari langsung ke bak pemeraman.

\subsection{Analisis Daya Dukung Fondasi Tiang Polos dan Tiang Kekasaran Hasil Interpretasi}

Analisis daya dukung fondasi tiang polos ini untuk menentukan daya dukung ultimit berdasarkan metode Terzaghi and Peck yaitu penurunan $25 \mathrm{~mm}$ (Q25). Beban dan penurunan yang digambarkan dengan grafik kemudian ditandai dengan garis lurus pada penetrasi $25 \mathrm{~mm}$ sampai menyentuh grafik gaya beban. Untuk melihat hasil pengujian daya dukung dari interpretasi Terzaghi and Peck penelitian ambil contoh tiang polos 0 hari dengan tiang polos 64 hari.

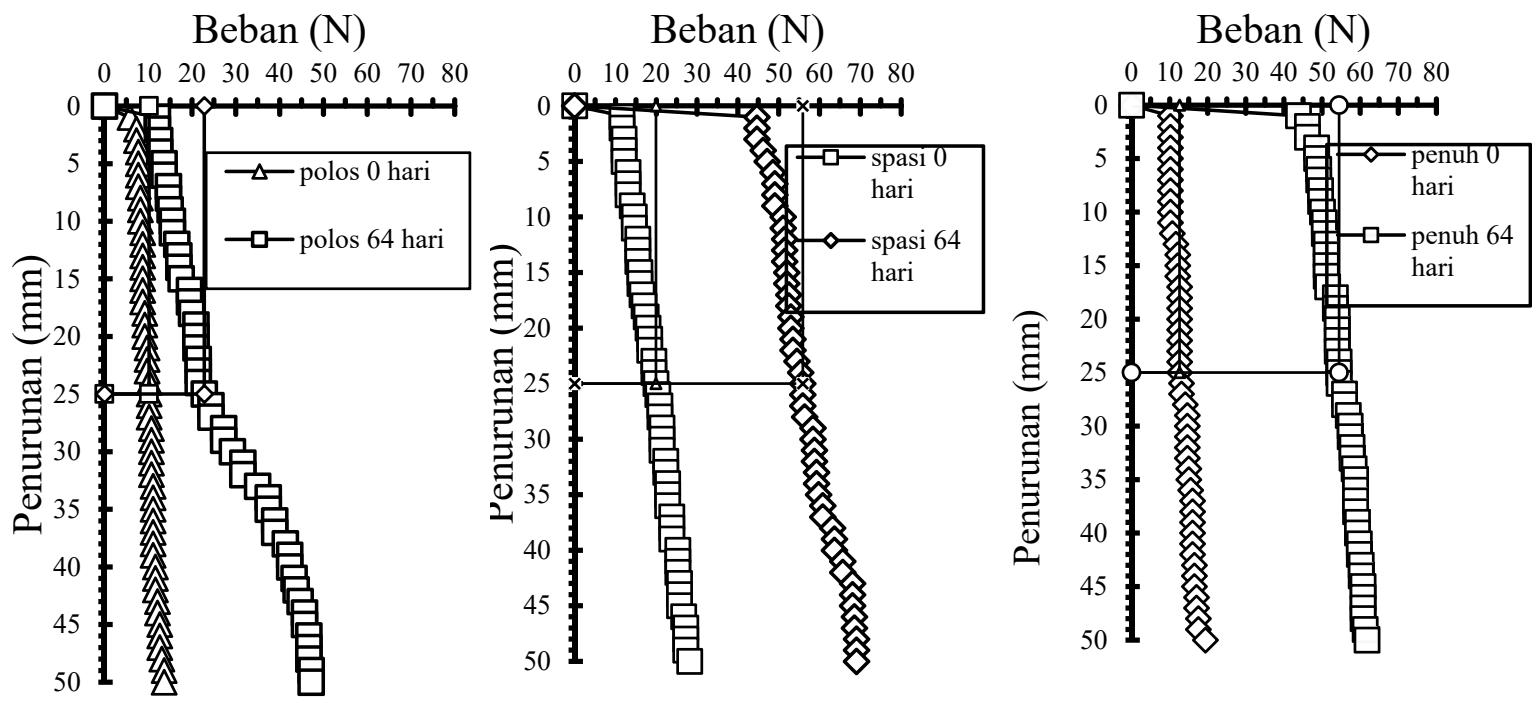

Gambar 9. Penurunan (mm) dengan Beban (N)

Gambar 9 memperlihatkan penurunan dengan beban merupakan hasil dari interpretasi daya dukung fondasi tiang polos dan tiang kekasaran spasi dan penuh pada pengujian pembebanan 0 hari dan 64 hari dengan menggunakan metode Terzaghi dan Peck yang penurunann $25 \mathrm{~mm}$. Untuk hasil pengujian pembebanan tiang fondasi 0 hari pada tiang polos 10,2 N, tiang kekasaran penuh 12,6 N dan tiang kekasaran spasi 19,9 N. Sedangkan untuk pengujian pembebanan pada 64 hari untuk tiang polos $22,8 \mathrm{~N}$, tiang kekasaran penuh $54,5 \mathrm{~N}$ dan tiang kekasaran spasi 55,9 N. untuk lebih lengkapnya dapat dilihat pada Tabel 3.

Tabel 3. Interpretasi Daya Dukung Tiang Menggunakan Metode Terzaghi dan Peck

\begin{tabular}{llll}
\hline $\begin{array}{l}\text { Waktu Pengujian } \\
\text { Pembebanan }\end{array}$ & Kekasaran Spasi & Kekasaran Penuh & Kekasaran Polos \\
\hline Hari & Qult $(\mathrm{N})$ & Qult $(\mathrm{N})$ & Qult $(\mathrm{N})$ \\
\hline 0 & 19,9 & 12,6 & 10,2 \\
\hline 4 & 22,8 & 21,8 & 11,6 \\
\hline 8 & 24,8 & 21,9 & 12,1 \\
\hline 16 & 25,2 & 22,2 & 16,9 \\
\hline 32 & 41,3 & 40,2 & 21,9 \\
\hline 64 & 55,9 & 54,5 & 22,8 \\
\hline
\end{tabular}




\subsection{Pengaruh Waktu Terhadap Peningkatan Kapasitas Daya Dukung}

Daya dukung ultimit (Qult) dari hasil penelitian ini telah didapatkan dengan cara analisis dari pengujian di lapangan metode Terzaghi and Peck (1967). Terdapat enam jenis tiang yang diuji yaitu dua jenis tiang dengan kekasaran spasi, dua jenis tiang dengan kekasaran penuh dan dua jenis tiang polos. Dengan variasi waktu $0,4,8,16,32$, dan 64 hari, hasil dari analisis pengaruh waktu terhadap kapasitas daya dukung fondasi dijelaskan dengan metode berikut.

\subsubsection{Perhitungan Kapasitas Daya Dukung Aksial Referensi ( $\left.Q_{0}\right)$}

Kapasitas daya dukung referensi $\left(\mathrm{Q}_{0}\right)$ adalah kemampuan atau kapasitas tiang dalam mendukung beban berdasarkan rekomendasi dari para ahli yang pernah melakukan penelitian tentang daya dukung fondasi terhadap waktu. Skov and Denver (1988), Bullock (2005), A. H. Augustesen (2006), . Keempat ahli tersebut menyatakan bahwa kapasitas daya dukung fondasi berada waktu referensi $\left(t_{0}\right)$, dengan umur pemancangan tiang1 hari $\left(t_{0}=1\right.$ hari). Kapasitas daya dukung referensi tiang ditentukan berdasar persamaan regresi linier dengan menggunakan grafik semi log.

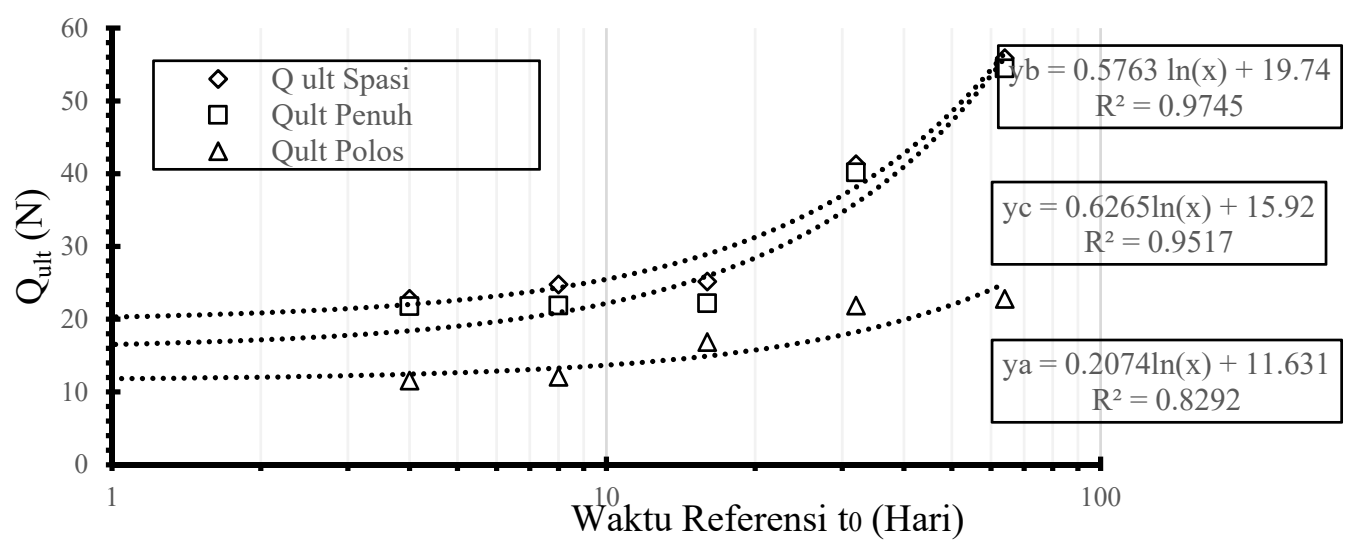

Gambar 10. Hubungan antara $Q_{u l t}$ Metode Terzaghi dengan Waktu referensi to

Gambar 10 menjelaskan hubungan antara $Q_{u l t}$ metode terzaghi dengan waktu referensi adalah untuk mendapatkan nilai daya dukung referensi fondsi tiang dengan menggunakan persamaan garis regresi linier, dimana waktu referensinya adalah 1 hari. Sehingga diperoleh nilai kapasitas daya dukung tiang polos disimbol (ya), tiang kekasaran spasi (yb) dan tiang kekasaran penuh (yc).

\subsubsection{Rasio Kapasitas Daya Dukung Referensi (rt)}

Rasio kapasitas daya dukung referensi adalah perbandingan nilai $Q_{u l t}$ dengan kapasitas aksial referensi $\left(Q_{0}\right)$. Untuk nilai rasio kapasitas daya dukung referensi untuk tiang polos, tiang kekasaran spasi dan tiang kekasaran penuh dapat dilihat pada table 4. 
Tabel 4. Nilai Rasio Qult Terhadap Qo

\begin{tabular}{lllllll}
\hline $\begin{array}{l}\text { waktu } \\
\text { pengujian } \\
\begin{array}{l}\text { Pembebanan } \\
\text { Hari }\end{array}\end{array}$ & Polos & Rasio & $\begin{array}{l}\text { kekasara } \\
\text { n spasi }\end{array}$ & Rasio & $\begin{array}{l}\text { kekasaran } \\
\text { penuh }\end{array}$ & Rasio \\
\hline 0 & Qult $(\mathrm{N})$ & $(г \mathrm{t} 1)$ & Qult $(\mathrm{N})$ & $($ гt2) & Qult $(\mathrm{N})$ & $($ гt3) \\
\hline 4 & 10,2 & 0,88 & 19,9 & 1,01 & 12,6 & 0,79 \\
\hline 8 & 11,6 & 1,00 & 22,8 & 1,16 & 21,8 & 1,37 \\
\hline 16 & 12,1 & 1,04 & 24,8 & 1,26 & 21,9 & 1,38 \\
\hline 32 & 16,9 & 1,45 & 25,2 & 1,27 & 22,2 & 1,39 \\
\hline 64 & 21,9 & 1,88 & 41,3 & 2,09 & 40,2 & 2,53 \\
\hline
\end{tabular}

\subsubsection{Penentuan Faktor Peningkatan $\left(\Delta_{10}\right)$}

Faktor peningkatan $\Delta_{10}$ merupakan faktor peningkatan yang menunjukan pengaruh waktu terhadap peningkatan kapasitas dukung aksial pada fondasi tiang tunggal. Besarnya pengaruh waktu pada peningkatan kapasitas aksial model fondasi tiang baik fondasi tiang dengan kekasaran spasi, fondasi tiang dengan kekasaran penuh dan fondasi tiang polos dapat dilihat pada Gambar 11. yaitu hubungan rasio dengan waktu pengujian yang dilkakukan.

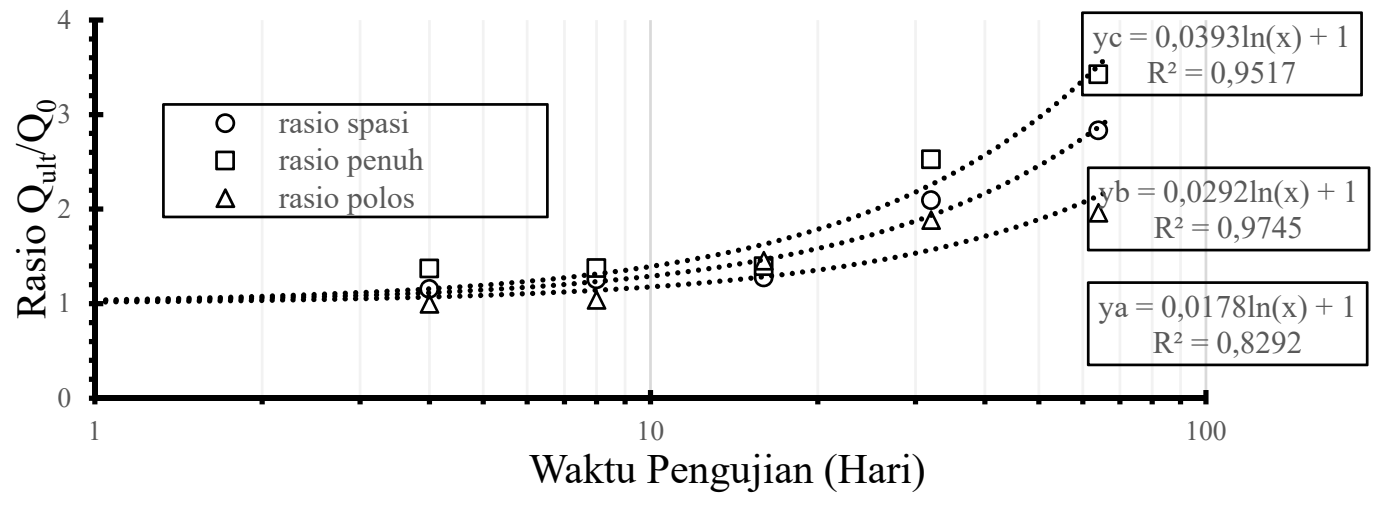

Gambar 11. Hubangan Rasio dengan Waktu pengujian

Persamaan garis linier untuk masing-masing tiang didapatkan dari grafik hubungan rasio $\mathrm{Q}_{\text {ult }} / \mathrm{Q}_{0}$ dengan waktu pengujian pada Gambar 11. Dimana (Ya) untuk tiang polos, (Yb) untuk tiang kekasaran spasi dan (Yc) untuk tiang kekasaran penuh. Hal ini disebabkan oleh pengaruh waktu terhadap kapasitas daya dukung aksial pada fondasi tiang tunggal yang pemeraman dan diuji sesuai dengan jadwal pengujian pembebanan $0,4,8,16,32$, dan 64 hari. Untuk memdapatkan faktor peningkatan dapat menggunakan persamaan dibawah ini.

$\mathrm{Qt}=\mathrm{QO} \cdot\{1+\Delta 10 \cdot \log 10(\mathrm{t} / \mathrm{tO} .1)$

Dengan demikian, dapat diambil besarnya rasio sesuai persamaan

$\mathrm{rt}=1+\Delta 10 \cdot \log 10(\mathrm{t} / \mathrm{t} 0)$ 


\section{SIMPULAN}

Simpulan dari penelitian ini yaitu :

1. Kapasitas daya dukung fondasi tiang dengan metode Terzaghi dan Peck mengalami kenaikan. Kapasitas daya dukung tiang dengan hasil pengujian pembebanan pada kekasaran spasi untuk umur 0 hari sebesar 19,9 $\mathrm{N}$ dan umur 64 hari sebesar 55,9 $\mathrm{N}$. Fondasi tiang dengan kekasaran penuh untuk umur 0 hari sebesar 12,6 $\mathrm{N}$ dan umur 64 hari sebesar 54,5 N. Untuk fondasi tiang polos pada umur 0 hari sebesar 10,2 $\mathrm{N}$ dan umur 64 hari sebesar 22,8 N. Dari tiga jenis tiang tersebut, tiang polos memiliki nilai peningkatan kapasitas daya dukung yang kecil.

2. Peningkatan daya dukung ditunjukan dengan faktor peningkatan $\left(\Delta_{10}\right)$. Pada tiang fondasi kekasaran spasi sebesar 0,07. Untuk fondasi tiang kekasaran penuh memiliki nilai sebesar 0,09. Dan fondasi tiang polos memiliki nilai sebesar 0,04. Dari tiga jenis tiang tersebut $(\Delta 10)$ paling besar terdapat pada fondasi tiang dengan kekasaran penuh.

3. Ketiga tiang tersebut yaitu tiang polos, tiang kekasaran spasi dan penuh memiliki nilai kapasitas daya dukung aksial yang berbeda seiring dengan waktu. Dari penelitian ini menunjukan tiang kekasaran memiliki nilai kapasitas daya dukung aksial yang paling besar dan tiang polos dengan kapasitas daya dukung aksial peling rendah. Seiring waktu kapasitas daya dukung aksial mengalami peningkatan dari umur 0,4,8,16,32 dan 64 hari.

\section{DAFTAR PUSTAKA}

Arianto. (2010). Analisis Parameter Geser Tanah Dengan Geotek. Universitas Muhammadiyah, Surakarta.

Augustesen, A., Andersen, L., \& Sørensen, C. S. (2005). Capacity of Piles in Clay. Aalborg University, Denmark.

Augustesen, A. H. (2006). The Effects of Time on Soil Behaviour and Pile Capacity. Aalborg University, Denmark.

Bowles, J. E. (1991). Sifat-sifat Fisis dan Geoteknis Tanah (Mekanika Tanah). Jakarta: Erlangga.

Bullock, P. J. (2005). Side Shear Set-up. I: Test Piles Driven in Florida. Journal of Geotechnical \& Geoenvironmental Engineering, 131(3), 292-300.

D'Applonia, D. J. (1971). Effects of foundation construction on nearby structures. Proceeding of the 4th Panamerican Conference on Soil Mechanics and Foundation Engineering, 2.

Komurka, V. E., Wagner, A. B., \& Edil, T. B. (2003). Estimating Soil/Pile Set-Up. U.S.A: Wisconsin Highway Research Program, Wisconsin Department of Transportation.

Lied, E. K. W. (2010). A Study of Time Effects on Pile Capacity.

Ravishankar, K. (2006). Effect of Soil Setup on Pile Capacity of Driven Piles. U.S.A: HNTB Corporation.

Skov, R., \& Denver, H. (1988). Time-dependence of bearing capacity of piles. Canada.

Svinkin, \& Mark, R. (1997). Time-Dependent Capacity Of Piles in Clayey Soil by Dynamic Methods. Proc.XIVth International Confrence on soil Mechanics and Foundation Engineering, Hamburg, 6-12 September, Rotterdam, Belkema, 2, 1045-1048.

Terzaghi, K., \& Peck, R. B. (1967). Soil Mechanics in Engineering Practice. New York: Jhon Wiley $\&$ Sons.

Wesley, L. D. (1977). Mekanika Tanah (cetakan ke VI). Jakarta: Bandan Penerbit Pekerjaan Umum. 